\title{
Determination of specific IgA antibodies to varicella zoster virus by immunoperoxidase assay
}

\author{
HAVA HAIKIN, ISRAEL SAROV \\ From the Virology Unit, Soroka University Hospital and Faculty of Health Sciences, Ben Gurion University \\ of the Negev, Beer Sheva, Israel
}

SUMMARY An indirect peroxidase technique was developed for determination of $\operatorname{IgA}$ antibodies to varicella zoster virus (VZV). The antigen consisted of acetone-fixed trypsinised VZV-infected cells. Rabbit antihuman IgA peroxidase conjugate was used to detect human IgA antibodies bound to viral antigen. In parallel IgG antibodies to VZV were determined by an immunoperoxidase antibody to membrane antigen (IPAMA) technique. Varicella zoster virus IgA antibodies were detected in all five varicella and seven zoster patients. No VZV IgA antibodies $(<2)$ were detected in 45 healthy control sera. Neither were they found in paired sera of five patients with herpes simplex infection, five patients with human cytomegalovirus infection and two patients with Epstein-Barr virus infection. Application of immunoperoxidase IgA technique in serodiagnosis of primary and reactivated VZV infections is discussed.

Varicella (chickenpox) is a mild, highly communicable disease caused by initial exposure to varicella zoster virus (VZV). After the patient recovers VZV persists in a latent form, and when reactivated, may cause zoster, characterised by a painful vesicular eruption limited to one or more segmented dermatomes. ${ }^{1}$ Varicella and zoster can cause severe complications in cases with malignant disease or those who are immunocompromised. ${ }^{2}$ It is, therefore, important to have a highly sensitive method for accurately detecting both primary and reactivated VZV infections.

Use of either immunofluorescent or immunoperoxidase techniques for detection of specific IgG antibodies to VZV-induced membrane antigen has been found valuable in determination of immune status, and in serodiagnosis of varicella and zoster infection when paired sera taken during acute and convalescent stages of the disease are examined. ${ }^{3-5}$ A highly sensitive radioimmunoassay (RIA) and an enzyme-linked immunosorbent assay (ELISA) for detection of specific VZV IgG antibodies have been also developed recently in a number of laboratories. ${ }^{6-9}$ As far as VZV-specific IgM is concerned, it has become apparent that it is produced regularly in varicella patients, but has been detected only in some zoster patients. ${ }^{7}$ 10-12

The purpose of this study was to develop an

Accepted for publication 16 November 1981 immunoperoxidase assay for the detection of VZVspecific IgA antibodies and to evaluate the feasibility of this approach for serodiagnosis of both primary and reactivated VZV infection.

\section{Material and methods}

CELLS AND MEDIA

Human embryonic fibroblasts (HEF) were grown in minimum essential medium (MEM, Biolab, Jerusalem, Israel), supplemented with $10 \%$ fetal calf serum (FCS) (Gibco, Biological Co, Grand Island, NY), $1 \%$ glutamin (Biolab), 100 units of penicillin/ml and $200 \mu \mathrm{g}$ of streptomycin/ml, $\mathrm{pH} 7 \cdot 2$.

\section{VZV ANTIGEN PREPARATION}

The cells were infected with VZV (Nurit strain, isolated in 1973 from a patient with chickenpox by SLK)..$^{1314}$ Infected cultures were incubated at $35^{\circ} \mathrm{C}$ in MEM supplemented with $2 \%$ FCS at pH 8.0 until cytopathic effects were observed in $60 \%-80 \%$ of the cells (24-48 $\mathrm{h}$ after inoculation).

Cells were removed from the glass with Versenetrypsin solution (Biolab) and washed with $0.01 \mathrm{M}$ phosphate-buffered saline (PBS), pH 7.4. Drops of twice-washed cell suspension, containing $10^{6}$ infected cells $/ \mathrm{ml}$ mixed with $2 \times 10^{5}$ uninfected cells $/ \mathrm{ml}$, were placed on glass slides, dried at room temperature (about $24^{\circ} \mathrm{C}$ ) and acetone-fixed. The slides were 
stored at $-20^{\circ} \mathrm{C}$. Titres of antibody to VZV remained unchanged even when slides were examined three months after preparation.

\section{HUMAN SERA}

Serum samples were obtained from 12 patients with clinical diagnosis of varicella or zoster, five with cytomegalovirus (CMV) infection, five with herpes simplex virus (HSV) infection, two with Epstein-Barr virus (EBV) infection and from 45 laboratory personnel and medical students.

\section{IMMUNOPEROXIDASE TECHNIQUE}

Stored slides were thawed and covered with twofold dilutions of test serum or control serum. After incubation at $37^{\circ} \mathrm{C}$ for $30 \mathrm{~min}$, followed by $15 \mathrm{~min}$ in PBS, slides were incubated for an additional $30 \mathrm{~min}$ with antihuman IgA peroxidase conjugate (specific for $\alpha$ chain, Dako, Copenhagen, Denmark), diluted $1 / 20$ in PBS. After washing, enzymatic activity was detected using the method of Graham and Karnovsky, ${ }^{15}$ as modified by Haikin and Sarov. ${ }^{16}$ The freshly prepared substrate solution was composed of $4 \mathrm{mg}$ benzidine (Riedel-de Haën, Seelze-Hannover) dissolved in $0.5 \mathrm{ml}$ acetone, $9.5 \mathrm{ml}$ PBS, and $10 \mu \mathrm{l}$ hydrogen peroxide from a $33 \%$ stock solution. Slides were incubated with substrate at room temperature for $5 \mathrm{~min}$ and were washed with PBS. Each test included known positive and negative sera, and reproducibility of the titration was demonstrated by testing the same positive sera several times.

The immunoperoxidase antibody to VZV membrane antigen (IPAMA) technique for detection of virus-specific IgG has been previously described. ${ }^{5}$

\section{Results}

\section{IMMUNOPEROXIDASE POSITIVE AND}

NEGATIVE REACTION

The Figure demonstrates the dark blue peroxidasecatalysed positive reaction in the nuclei of infected human embryo cells after incubation with VZV-IgApositive sera derived from varicella and zoster patients; staining was absent when VZV-IgAnegative sera were examined. Antihuman IgA peroxidase conjugate diluted $1 / 20$ was found satisfactory for detection of specific VZV-IgA antibodies. Lower dilutions showed non-specific cytoplasmic staining while higher dilutions failed to detect low levels of VZV-IgA antibodies.

\section{REPRODUCIBILITY}

We examined the reproducibility of the test by testing three VZV-IgA-positive sera several times. The titre was reproducible within a twofold range.

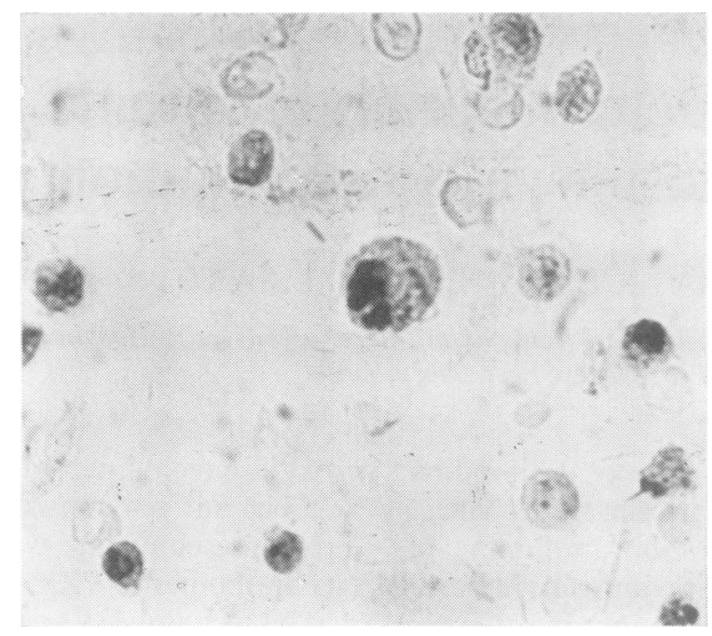

Immunoperoxidase staining of $V Z V$-infected human embryonic fibroblasts (IgA-positive serum) $\times 250$.

SPECIFICITY OF IMMUNOPEROXIDASE ASSAY The specificity of the method was tested with regard to cross-reactivity with other herpes group viruses. Paired sera of five patients with clinical and serological diagnosis of acute HSV infection, five patients with CMV mononucleosis and two patients with EBV infection were found to be VZV IgA negative $(<2)$.

\section{VARICELLA AND ZOSTER PATIENTS}

Sera from five varicella and seven zoster patients were tested for VZV-IgG and IgA antibodies by the immunoperoxidase technique. For all the patients VZV-specific IgA was detected in one or more serum samples (Table). In sera of three patients with varicella $(1,2,5)$ and two patients with zoster $(9,10)$ infection, peroxidase staining was observed in the nuclei of VZV-infected human embryo fibroblasts while membrane staining was observed in the other samples. In three of the varicella patients $(2,3,5)$ IgA antibodies began to decline one month after the onset of the disease. Decrease of VZV IgA titre was seen 45 days after onset of rash in two of the zoster patients $(10,12)$. In one patient (6) a single serum sample was available after one year. This sample was still slightly positive for VZV-specific IgA.

\section{CONTROL-HEALTHY ADULTS}

Forty-four medical students seropositive for VZVspecific IgG (and one seronegative) were tested for VZV-specific IgA antibodies and were found negative $(<2)$. The possibility that $\mathrm{VZV} \operatorname{IgA}$ 
Immunoperoxidase antibody titres of patients with VZV infection

\begin{tabular}{|c|c|c|c|c|c|c|}
\hline \multirow[t]{2}{*}{ Patient No } & \multirow[t]{2}{*}{$\operatorname{Age}(y r)$} & \multirow[t]{2}{*}{$\operatorname{Sex}$} & \multirow[t]{2}{*}{ Day of illness* } & \multirow[t]{2}{*}{ Diagnosis } & \multicolumn{2}{|c|}{ Antibody titre } \\
\hline & & & & & $\operatorname{Ig} G$ & $\operatorname{Ig} A$ \\
\hline 1 & 5 & $\mathbf{M}$ & $\mathbf{U}$ & Necrotising varicella & 320 & 16 \\
\hline \multirow{3}{*}{2} & 30 & $\mathbf{M}$ & U & varicella & 2 & 2 \\
\hline & & & $12 \dagger$ & & $>128$ & 16 \\
\hline & & & $30+$ & & ND & 2 \\
\hline \multirow{3}{*}{3} & 6 & $\mathbf{F}$ & 10 & varicella & 16 & $<4$ \\
\hline & & & 15 & & 320 & 4 \\
\hline & & & 30 & & 320 & $<4$ \\
\hline \multirow[t]{2}{*}{4} & 12 & $\mathbf{F}$ & 3 & varicel!a & 2 & $<2$ \\
\hline & & & 21 & & $>64$ & 16 \\
\hline \multirow[t]{3}{*}{5} & 6 & $\mathbf{F}$ & 10 & varicella & 16 & 8 \\
\hline & & & 13 & & 32 & 4 \\
\hline & & & 28 & & 64 & $<2$ \\
\hline \multirow[t]{4}{*}{6} & 56 & $\mathbf{M}$ & 3 & zoster & 2 & $<2$ \\
\hline & & & 21 & & $\geqslant 128$ & 32 \\
\hline & & & 75 & & 160 & 16 \\
\hline & & & $1 \mathrm{yr}$ & & 20 & 4 \\
\hline \multirow[t]{2}{*}{7} & 54 & $\mathbf{F}$ & 6 & zoster & $\geqslant 128$ & 16 \\
\hline & & & 14 & & $\geqslant 128$ & 8 \\
\hline \multirow[t]{3}{*}{8} & 54 & $\mathbf{M}$ & 7 & zoster & 4 & ND \\
\hline & & & 14 & & $\geqslant 128$ & 40 \\
\hline & & & 60 & & $\geqslant 128$ & 20 \\
\hline \multirow{2}{*}{9} & 79 & $\mathbf{M}$ & 4 & zoster & $\geqslant 128$ & 20 \\
\hline & & & 11 & & $\geqslant 128$ & 40 \\
\hline \multirow{2}{*}{10} & 78 & $F$ & 5 & zoster & $\geqslant 128$ & 10 \\
\hline & & & 45 & & $\geqslant 128$ & 4 \\
\hline \multirow[t]{3}{*}{11} & 50 & $\mathbf{F}$ & 2 & zoster & 2 & $<4$ \\
\hline & & & 14 & & 128 & 16 \\
\hline & & & 180 & & 20 & $<4$ \\
\hline \multirow[t]{5}{*}{12} & 57 & $\mathbf{F}$ & 5 & zoster & $>128$ & 16 \\
\hline & & & 7 & & $\geqslant 128$ & 32 \\
\hline & & & 13 & & 128 & 32 \\
\hline & & & 46 & & 32 & ND \\
\hline & & & 49 & & 32 & 8 \\
\hline
\end{tabular}

*Days after onset of rash.

†Days after first sample.

$\mathrm{U}=$ unknown. ND $=$ not done.

might be detected at titres lower than two in control sera needs to be examined.

\section{Discussion}

In the present study we have developed a simple immunoperoxidase assay for detection of specific IgA to VZV. VZV IgA antibodies were detected in all varicella and zoster patients but not in any $(<2)$ of the control sera from 44 healthy individuals seropositive for VZV. Neither was VZV IgA detected $(<2)$ in paired sera of patients with HSV, CMV or EBV infections. The possibility that VZVIgA antibodies can be detected in serum of healthy persons by a highly sensitive radioimmunoassay technique recently developed in this laboratory 617 is being investigated. Brunnel et al ${ }^{18}$ described VZV specific IgA antibody production in a number of varicella and zoster patients they studied by the immunofluorescent technique. We have recently shown by examination of sera from patients with CMV mononucleosis and from kidney transplant recipients that in both primary and recurrent CMV infections, IgA antibodies were detected at high titre by the ELISA technique. ${ }^{19-22}$ Thus specific IgA production seems not to be restricted to primary VZV and CMV infection, but can also be a signal of reactivation or reinfection by these viruses.

Detection of VZV-specific IgA antibodies in both varicella and zoster patients by the immunoperoxidase assay implies that this technique can be of value in the serodiagnosis of VZV infections, using a single serum sample of the "convalescent phase." In order to evaluate properly the potential application of this VZV-IgA peroxidase assay as a standard technique for serodiagnosis of VZV infection, the persistence of specific VZV-IgA antibodies needs to be examined in a large number of patients. In three varicella patients $(2,3,5) \operatorname{IgA}$ antibodies seemed to decline within a month. With regard to zoster patients VZV-IgA antibodies began to decline after about 45 days.

The persistence of IgA antibodies after other viral infections seems to depend largely on the virus involved, on individual variation among the subjects tested and probably most importantly on the sensitivity of the method used to detect specific IgA.12 20 23-27 However, with regard to herpes group 
viruses which may be reactivated, when specific IgM could be detected only in some of these patients $^{12} 222829$ the appearance of specific IgA may be a clear indication of viral reactivation.

In summary, the present study demonstrates that specific IgA antibodies could be detected by the immunoperoxidase techrique in the course of primary and reactivated VZV infections. The method is simple and rapid to perform. Moreover, it can be applied to stored target cells which can be used as and where needed. The immunoperoxidase assay is much more convenient than the immunofluorescent antibody test because there is no need for a fluorescent microscope and the results can be read with a simple light microscope. We are currently examining the interesting possibility that specific IgA may be detected in a number of neurological, autoimmune diseases and in human cancer in which an aetiological relation with herpes viruses has been suggested ${ }^{30-37}$

This study was supported by the P Sapir Foundation. Thanks are due to Mr Y Ruham, Mrs O Iosub and Mrs D Frenkel for photographic assistance.

\section{References}

${ }^{1}$ Hope-Simpson RE. The nature of herpes zoster: a longterm study and a new hypothesis. Proc $R$ Soc Med 1965; 58:9-10.

2 Haynes RE. Varicella zoster infections in normal and compromised hosts. In: Galasso GJ, Merigan TC, Buchanan RA, eds. Antiviral agents and viral diseases of man. New York: Raven Press, 1979:647-79.

${ }^{3}$ Williams V, Gershon A, Brunell PA. Serologic response to varicella zoster membrane antigens measured by indirect immunofluorescence. J Infect Dis 1974;130: 669-72.

4 Gerna G, Achilli G, Chambers RW. Determination of neutralising antibody and IgG antibody to varicellazoster virus and of $\operatorname{lgG}$ antibody to membrane antigens by the immunoperoxidase technique. J Infect Dis 1977; 135:975-9.

${ }^{5}$ Haikin $\mathrm{H}$, Leventon-Kriss S, Sarov I. Antibody to varicella zoster virus-induced membrane antigen: Immunoperoxidase assay with air-dried target cells. J Infect Dis 1979;140:601-4.

- Friedman MG, Leventon-Kriss S, Sarov I. Sensitive solid-phase radioimmunoassay for detection of human immunoglobulin $\mathrm{G}$ antibodies to varicella zoster virus. J Clin Microbiol 1979;9:1-10.

${ }^{7}$ Arvin AM, Koropchack CM. Immunoglobulins M and G to varicella zoster virus measured by solid phase radioimmunoassay: Antibody responses to varicella and herpes zoster infections. J Clin Microbiol 1980;12:374-6.

${ }^{8}$ Campbell-Benzie A, Kangro HO, Heath RB. The development and evaluation of a solid phase radioimmunoassay (RIA) procedure for the determination of susceptibility to varicella. $J$ Virol Methods $1981 ; 2: 149-58$.

${ }^{9}$ Goldberg RD, Sarov I. Enzyme linked immunosorbent assay for the detection of antibodies to varicella zoster virus. Isr J Med Sci 1980;16:111-7.

${ }^{10}$ Ross CHC, McDaid R. Specific IgM antibody in serum of patients with herpes zoster infections. Br Med J 1972; iv:522-3.

${ }^{11}$ Schmidt NJ, Lennette EH. Neutralising antibody responses to varicella-zoster virus. Infect Immun 1975;12:606-13.

${ }^{12}$ Hacham M, Leventon-Kriss S, Sarov I. Enzyme-linked immunosorbent assay for detection of virus-specific IgM antibodies to varicella-zoster virus. Intervirology 1980; 13:214-22.

${ }^{13}$ Leventon-Kriss S, Joffe R, Rannon L, Modan M. Seroepidemiologic aspects of varicella zoster virus infections in an Israeli Jewish population. IsrJ Med Sci 1978;14:766-70.

${ }^{14}$ Shemer Y. Leventon-Kriss S, Sarov I. Isolation and polypeptide characterisation of varicella-zoster virus. Virology 1980;106:133-40.

${ }^{15}$ Graham R Jr., Karnovsky M. The early stages of absorption of injected horseradish peroxidase in the proximal tubule of mouse kidney: ultrastructural cytochemistry by a new technique. $J$ Histochem Cytochem 1966;14: 291-306.

${ }^{16}$ Haikin H, Sarov I. Immunoperoxidase antibody to human cytomegalovirus-induced membrane antigen assay in the absence of interfering immunoglobulin $G$ receptors. Intervirology 1980;14:155-9.

17 Friedman M. Salivary IgA antibodies to mumps virus during and after mumps. J Infect Dis 1981;143:617.

18 Brunnel PA, Gershon AA, Uduman SA, Sternberg S. Varicella-zoster immunoglobulin during varicella, latency and zoster. J Infect Dis 1975;132:49-54.

${ }^{19}$ Sarov I. Detection of antibodies for human cytomegalovirus (CMV) by enzyme immunoassay and radioimmunoassay techniques. In: Touraine $\mathrm{JL}$, Traeger $\mathrm{J}$, Betuel H, et al, eds. Transplantation and clinical immuno$\log y$ XII. Lyon: Excerpta Medica, 1980:50-4.

${ }^{20}$ Levy E, Sarov I. Determination of IgA antibodies to human cytomegalovirus by enzyme-linked immunosorbent assay (ELISA). J Med Virol 1980;6:249-57.

${ }^{21}$ Sarov I, Siqueira-Linhares M, Chardonnet Y, Levy E, Aymard M, Bosshard S, Nord E, Revillard JP. Detection of IgA antibodies in serum of kidney transplant patients with recurrent cytomegalovirus infection. Intervirology $1981 ;$;15:228-34.

${ }^{22}$ Sarov I, Siqueira-Linhares M, Chardonnet Y, Levy E, Aymard M, Bosshard S, Nord E, Revillard JP. Determination of IgA antibodies to human cytomegalovirus by enzyme linked immunosorbent assay (ELISA). Abstract, Fifth International Congress of Virology. Strasbourg, France, 1981:155.

${ }^{23}$ Nikoskelainen J, Neil EU, Stevens DA. Epstein-Barr virus specific serum immunoglobulin $A$ as an acute phase antibody in infectious mononucleosis. J Clin Microbiol 1979;10:75-9.

${ }^{24}$ Halonen P, Bennich H, Torfason E, Karlsson T, Ziola B, Matikainen M, Hjertsson E, Wesslen T. Solid-phase radioimmunoassay of serum immunoglobulin $A$ antibodies to respiratory syncitial virus and adenovirus. $J$ Clin Microbiol 1979;10:192-7.

${ }^{25}$ Halonen P, Meurman C, Matikainen MT, Torfason E, Bennick $H$. IgG antibody response in acute rubella determined by solid-phase radioimmunoassay. $\mathrm{J} \mathrm{Hyg}$ (Camb) 1979;83:69-75.

${ }^{26}$ Brown GC, O'Leary TP. Fluorescent antibodies to influenza virus in various immunoglobulin fractions of serum after natural infection or vaccination. $J$ Immunol $1973 ; 110: 889-96$.

27 Hornsleth A, Leerhoy J, Granballe P, Spanggaard H. Persistence of rubella virus specific immunoglobulin A antibodies: Investigation of successive serum samples with lowered immunoglobulin G concentration. Infect Immun 1975;11:804-8.

${ }^{28}$ Schmidt NJ, Forghani B, Lennette EH. Type specificity of complement requiring and immunoglobulin $M$ neutral- 
izing antibody in initial herpes simplex virus infections of humans. Infect Immun 1975;12:728-32.

${ }^{29}$ Kalimo KOK, Marttila RJ, Granfors K, Viljanen MK. Solid-phase radioimmunoassay of human immunoglobulin $\mathbf{M}$ and immunoglobulin $\mathbf{G}$ antibodies against herpes simplex virus type 1 capsid, envelope and excreted antigens. Infect Immun 1977; 15:883-9.

${ }^{30}$ Henle G, Henle W. Epstein-Barr virus specific IgA serum antibodies as an outstanding feature of nasopharyngeal carcinoma. Int J Canc 1976;17:1-7.

${ }^{31}$ Dowling P, Menonna J, Cook S. Cytomegalovirus complement fixation antibody in Guillain-Barré syndrome. Neurology (Minneap) 1977;27:1153-6.

${ }^{32}$ Lycke $E$, Norrby $R$, Raos BE, A serological study on mentally ill patients with particular reference to the prevalence of herpes virus infections. Br J Psychiat 1974; 124:273-9.

${ }^{33}$ Tovi F, Sidi J, Haikin H, Sarov B, Sarov I. Viral infection and acute peripheral facial palsy. A study with herpes simplex and varicella-zoster viruses. Isr J Med Sci 1980; 16:576-80.
${ }^{34}$ Kahane S, Dvilansky A, Estok L, Nathan I, Zolotov Z, Sarov I. Detection of antiplatelet antibodies in patients with idiopathic thrombocytopenic purpura (ITP) and in patients with rubella and herpes group viral infections. $J$ Clin Exp Immunol 1981;44:49-57.

${ }^{35}$ Rawls WE, Bachetti S, Graham FL. Relation of herpes simplex viruses to human malignancies. Curr Top Microb Immunol 1977;77:71-95.

${ }^{36}$ Vahlne A, Edstrom S, Arstila P, Beran M, Ejnell $H$, Nylen O, Lycke E. Bell's palsy and herpes simplex virus. Arch Otolaryngol $1981 ; 107: 79-81$.

${ }^{37}$ Epstein MA. As assessment of the possible role of viruses in the etiology of Burkitt's lymphoma. Prog Exp Tumor Res 1978;21:72-99.

Requests for reprints to: Dr Israel Sarov, Virology Unit, Faculty of Health Sciences, Ben Gurion University of the Negev, Beer Sheva, Israel. 